\title{
Original Research \\ Improving Quality of Surface Waters with Coalition Projects and Environmental Subsidy Negotiation
}

\author{
Petr Šauer ${ }^{1 *}$, Petr Fiala ${ }^{1}$, Antonín Dvořák ${ }^{1}$ Ondřej Kolínský1, \\ Jan Prášek ${ }^{2}$, Petr Ferbar ${ }^{3}$, Luděk Rederer ${ }^{3}$ \\ ${ }^{1}$ University of Economics, Prague, Czech Republic \\ ${ }^{2}$ CENIA Praha, Czech Republic \\ ${ }^{3}$ Povodí Labe, State Enterprise, Hradec Králové, Czech Republic
}

Received: 12 May 2014

Accepted: 3 August 2014

\begin{abstract}
We can observe new reasons for improving water protection policies: climate change calls for higher security for drinking water sources, increasing demand for improving water quality for swimming purposes in recreational areas, higher pressure on responsibility for water quality crossing national borders. Our paper presents an application of combinatorial auction theory to the problem of cleaning waters in streams where individual polluters can create various coalitions when submitting proposals for financial support to individual or common projects. The practical case has shown significant savings of social costs if the coalition solutions are realized. There is an information asymmetry between the polluters when elaborating common application for an investment subsidy for their projects. A series of economic laboratory experiments was carried out to pretest subjects' potential behaviour here. The results showed that $75 \%$ of the groups found the (theoretical) first best solution. Subsidies required tended to be relatively low, making the competition for subsidies very stiff.
\end{abstract}

Keywords: water pollution, combinatorial auctions, environmental subsidy, economic laboratory experiments, information asymmetry

\section{Introduction}

Managing water pollution is one of the key problems of environmental policies. We can observe several stages in developed countries. After a period of terrible deterioration of the watercourses in the 1960s-80s, there was a period of significant improvement in the 1980s-90s (depending on the country and region) caused by dealing mostly with larger pollution sources. Currently we can observe new challenges and reasons for improving water protection policies:

*e-mail: sauer@vse.cz climate change, with its difficult-to-predict impacts on water regimes, calls for higher security for drinking water sources, an increasing demand for improving water quality for swimming purposes in recreational areas, and higher pressure on responsibility for water quality crossing national borders.

Planning and management of surface water protection programs and projects is a typical area of environmental protection where governments intervene. Various public funding programs for (especially public) capital investment projects in water protection are some of the typical forms of intervention (political instruments). Achieving at least 
close-to-cost-effective allocations of these sources is a standard (both theoretical and practical) requirement.

Until recently, building individual wastewater treatment plants (WWTP) at each city and town over 2000 inhabitants (according to [1]) has been the most frequent technological solution to the policy requirements. Dealing with relatively steep individual and aggregated wastewater treatment abatement curves and their potential shifts due to environmentally oriented technological progress were typical problems when struggling for high environmental efficiency of wastewater treatment.

The new policy strategies and goals assume solving river basin pollution problems at small pollution sources as well, and focusing on critical parts of large river basins. Due to the fact that these polluters are located near each other in many cases, a relatively new phenomenon enters the scene - various common projects to reduce water pollution are possible. For a similar idea see the U.S. Department of Agriculture's Mississippi River Basin Healthy Watersheds Initiative," where rather than working with dispersed individual polluters, a portion of conservation program funds is used to work with many cooperating polluters - farmers located in select, high-priority watersheds [2]. We would like our paper also to contribute to promoting "river basin management at the lowest appropriate level" [3].

This brings new challenges to the theory and practice of the social science side of the problem. Combinatorial auctions seem to be one of the most relevant methodological solutions that can be developed and applied. They help search for optimal (cost-efficient) solutions and calculate parameters of background models that can be used in economic laboratory experiments pre-testing subjects' behavior, especially in situations where there an information asymmetry between the regulator (authority, government) and polluters, and among the polluters. (For a review of experiments related to environmental markets see [4].)

The methodology that introduces the combinatorial auctions theory for solving the problem is described in the first part. For the theory of combinatorial auctions see [5, 6]. For an example of experimental testing the models of combinatorial auctions see [7].

An illustrative application is the case of a small river basin with four municipalities polluting Powder Brook, which is presented in the second part. In spite of some necessary simplifications, the authors have striven for maximum approximation to the real situation in one of the tributaries of the Elbe river basin near the Czech-Polish border. Similarly as in [8] and [9], it is a case where the (state) authority offers financial support to wastewater cleaning projects. In the present study, however, polluters apply for such support in multiple (1-4) member coalitions. A series of economic laboratory experiments was carried out to pre-test whether the subjects could find the optimal solution, i.e., find the optimal coalition, and what would be their total surplus and how the surplus would be divided among the parties under informational asymmetry. The institutional setting of the experiments in based on Czech legislation and the experiments allow us to eval- uate the proposed institutional changes with relatively low costs and in a short time [10]. These experiments are described in the third part of the paper.

\section{Background Methodology}

\section{Step-by-Step Process Description}

The whole procedure of initiating or updating river basin plans consists (when simplified) of six steps (Fig. 1). The provisions of [11-13] and their respective executive decrees $[14,15]$ create the policy background for this process in the Czech Republic. For more details about this methodology, see its pilot application in Section 3 of this paper (especially Tables 1-8) and [16].

When a decision is made about initiation of the plan acquisition or updating, the planner shall make or arrange to make an analysis of problems in water management in the area and then announce - e.g., as part of publishing a "Preliminary overview of major problems in water management" - the fact that sewage and wastewater treatment will be solved with respect to the facts identified in the area (step 2.1). In the next step (2.2), a draft list of individual and coalition designs for wastewater treatment projects is elaborated

1. Decision on initiation of plan acquisition or update

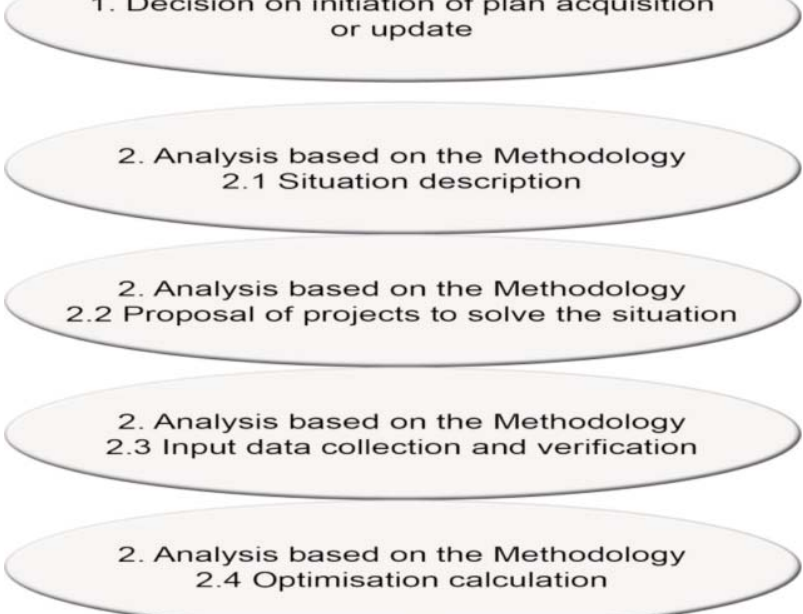

3. Elaboration of draft plan and comment procedure

\section{t}

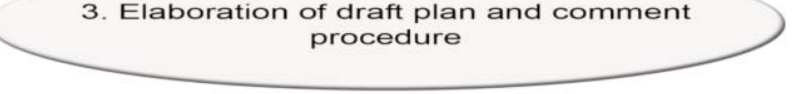

4. Environmental impact assessment

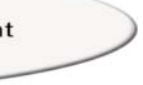

5. Draft plan approval

6. Plan publication

Fig. 1. Planner's work procedure using the methodology. 
Table 1. List of projects proposed for assessment pursuant to the methodology.

\begin{tabular}{|c|c|c|}
\hline Project No. & Project title & WWTP location \\
\hline \multicolumn{3}{|c|}{ Individual projects } \\
\hline 1. & A & by municipality A \\
\hline 2. & B & by municipality B \\
\hline 3. & C & by municipality C \\
\hline 4. & D & by municipality D \\
\hline \multicolumn{3}{|c|}{ Coalition projects } \\
\hline 1. & AB & by municipality B \\
\hline 2. & ABC & by municipality C \\
\hline 3. & BC & by municipality C \\
\hline 4. & CD & outside either municipality \\
\hline 5. & BD & \multirow{2}{*}{ at confluence of Powder Brook } \\
and Unnamed
\end{tabular}

(Table 1). The list includes all projects that evidently (based on an "expert's first sight") cannot be excluded for technical, economic, environmental, morphological, political (people in municipality $X$ may disagree with building a joint WWTP with municipality $Y$, even though it is an efficient option economically and otherwise), or institutional reasons (e.g., requirements for use of public subsidies rule out the project). There is a fact that may lead to an increase in the number of coalitions/projects. It is situation that a WWTP for an individual polluter or for a group of polluters may theoretically be located on one (usually near the last polluter downstream) or at multiple (alternative) sites.

Input data collection and verification is the next step (2.3). The analysis author shall produce the following information:

(i) Calculated wastewater production before and after WWTP implementation using indicators required by the legislation plus other indicators if important for the given case

(ii) Information on receiving watercourses into which the treated wastewater from the sites will be discharged is collected

(iii) The assessment of compliance with requirements on water discharge into surface waters (according to requirements specified by the Water Act and its executive decrees)

(iv) The most important for the issue discussed in our paper (search for cost-effective ways of the solution) is a cost estimate for all the individual and coalition designs (Table 8).

The cost estimate (an interval estimate is also possible) shall be made by the expert(s) based on the real expected costs of the respective technologies, typically consisting of
Table 2. Data on proposed projects - calculated wastewater production.

\begin{tabular}{|c|c|c|c|c|}
\hline \multirow{2}{*}{$\begin{array}{c}\text { Project } \\
\text { No. }\end{array}$} & \multirow{2}{*}{$\begin{array}{c}\text { Project } \\
\text { title }\end{array}$} & $\begin{array}{c}\text { Number of } \\
\text { EI }\end{array}$ & \multicolumn{2}{|c|}{$\begin{array}{c}\text { WW } \\
\text { production }\end{array}$} \\
\cline { 4 - 5 } & \multicolumn{5}{|c|}{ Individual projects } & $\left(\mathrm{m}^{3} /\right.$ dayear $)$ \\
\hline 1. & A & 100 & 15 & 5,475 \\
\hline 2. & B & 250 & 37.5 & $13,687.5$ \\
\hline 3. & C & 500 & 75 & 27,375 \\
\hline 4. & D & 750 & 112.5 & $41,062.5$ \\
\hline & & Coalition projects & \\
\hline 1. & AB & 350 & 52.5 & $19,162.5$ \\
\hline 2. & ABC & 850 & 127.5 & $46,537.5$ \\
\hline 3. & BC & 750 & 112.5 & $41,062.5$ \\
\hline 4. & CD & 1250 & 187.5 & $68,437.5$ \\
\hline 5. & BD & 1000 & 150 & 54,750 \\
\hline 6. & BCD & 1500 & 225 & 82,125 \\
\hline 7. & ABCD & 1600 & 240 & 87,600 \\
\hline
\end{tabular}

the WWTP investment costs, sewage investment costs, pumping station investment costs, and investment costs of other facilities that are acquired under the project (settlement pools, etc.).

An optimization calculation is carried out (see the following section Model for Optimizing Abatement Costs for details on the calculation methodology related to step 2.4 in Fig. 1) and its results enter the draft plan (step 3), which undergoes an internal and external comment procedure. The conclusions from the comment procedures have to be fully resolved - the comments are either accepted or their rejection is duly substantiated. One of the possible comments may be a requirement to include in the analysis additional, typically coalition projects or projects with different WWTP locations. It may also become evident that the first/previous round included a design/project that would have been unfeasible and is pointless to include in the optimization calculation. In such a case steps 2.2-2.4 are repeated and a new optimization calculation is made and the draft plan is modified according to its result.

The modified draft plan concept is then commented upon and assessed pursuant to Act No. 100/2001 Coll. on Environmental Impact Assessment [17] (step 4). The comments and position statements obtained within the environmental impact assessment are integrated into the draft plan. The final draft wording is prepared, including alternative options and required annexes. The draft is submitted to the superordinate authority for approval. If the plan is approved (step 5), it is subsequently published (step 6) on the specified website and becomes binding for the area in question. 


\section{Model for Optimizing Pollution Abatement Costs}

An optimization calculation is made for the approved possible individual and coalition designs (projects). Its purpose is to find a combination of projects, individual and coalition ones, that will achieve the set watercourse pollution reduction targets at the lowest costs.

The solution to this problem is based on the reverse combinatorial auction exercise. The reverse combinatorial auction problem is characterized by a single buyer (the environmental public authority in our case) and a larger number of sellers (municipalities-polluters in our case). The advantage of this model is that the number of polluters and their projects can be very large, which makes finding the optimal solution with an intuitive way quite difficult.

The buyer tries to buy at least the required set of items from the sellers at minimum costs. Let us assume that $m$ potential sellers $S_{1}, S_{2}, \ldots, S_{m}$ are offering set $R$ with $r$ items, $j=1,2, \ldots, r$, to the one buyer $B$ (Fig. 2).

The bid $b_{h}$ made by the seller $S_{h}, h=1,2, \ldots, m$, is defined as:

$$
b_{h}=\left\{C, c_{h}(C)\right\}
$$

...where $C \subseteq R$ is a combination of items, and $c_{h}(C)$ is the offered price by seller $S_{h}$ for the combination of items $C$.

The objective is to minimize the buyer's cost given the bids made by sellers. Constraints establish that the procurement provides at least a set of all items.

Bivalent variables are introduced for model formulation:

$y_{h}(C)$ is a bivalent variable specifying whether the combination $C$ is bought from the seller $S_{h}\left(y_{h}(C)=1\right)$.

The reverse combinatorial auction can be formulated as follows:

$$
\sum_{h=1}^{m} \sum_{C \subseteq R} c_{h}(C) y_{h}(C) \rightarrow \min
$$

subject to

$$
\begin{gathered}
\sum_{h=1}^{m} \sum_{C \subseteq R} y_{h}(C) \geq 1, \forall j \in R, \\
y_{h}(C) \in\{0,1\}, \forall C \subseteq R, \quad \forall h, h=1,2, \ldots, m .
\end{gathered}
$$

The criterion function expresses the objective, i.e., minimization of the buyer's (authority's) costs. The restriction ensures the purchase of the required set of items.

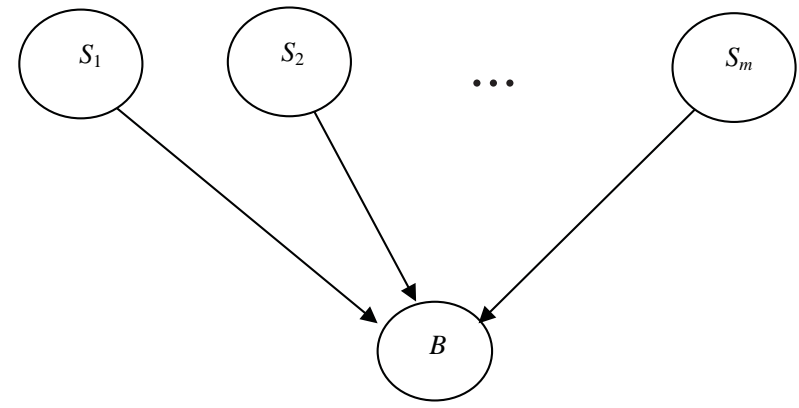

Fig. 2. Reverse auctions.
There is a question if or to which extent the optimum result can be achieved by means of a real auction in the case of information asymmetry between the subjects. We pretested behaviour in this situation by economic laboratory experiment (see the Laboratory Pre-Tests of Subject Behavior section).

Nevertheless, the optimum result can be calculated knowing the cost information determined by an educated estimate. The CRAB (CombinatoRial Auction Body Software System) can be used for more complex situation (i.e., larger number of designs being offered, particularly coalitions). It enables generating, solving and testing of combinatorial auction problems [18]. The system solves the problems using the Balas method or a primarily dual algorithm. Any solver for bivalent programming tasks can also be applied to solve the cheapest combination of preselected possible designs (projects).

The optimum combination of projects calculated is presented as a draft plan for the comment procedure (step 2.4 in Fig. 1).

\section{Powder Brook Case Study}

Based on legislative requirements of the Czech Republic, i.e., with respect to obligations specified by Section 22a of Water Act No. 254/2001 [12], the owner of the Catchment Plan has to make an update that will lead to an improvement in the Powder Brook catchment in order to ensure achievement of targets defined for surface waters pursuant to item (a) of said section. These targets should be achieved using the most cost-effective measures. The planner has decided to use the certified methodology briefly described in this paper for elaborating on the analytical documents.

\section{Situation Description}

The Powder Brook catchment (Fig. 3) contains municipalities A, B, and C. Municipality D lies in a sub-catchment of the Powder Brook (Unnamed). The two catchments are separated by the Titmouse Hills ridge, which is a nature

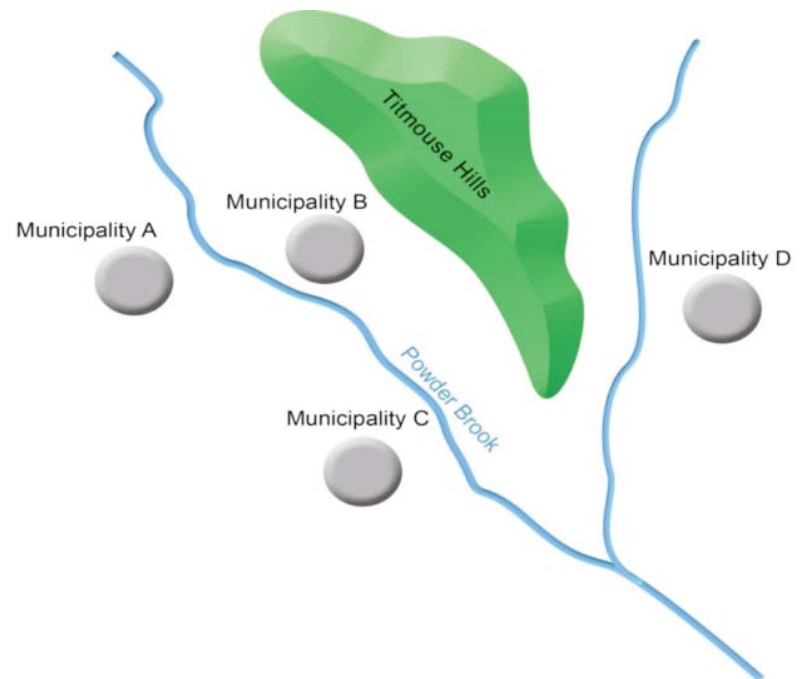

Fig. 3. Layout of the Powder Brook catchment. 
reserve. At present, wastewater is discharged directly into the watercourses of the Powder Brook and its Unnamed tributary. With the exception of municipalities C and D there are only minor pollution producers in the basin. In spite of this, it is necessary to design a way to significantly reduce the amounts of pollutants discharged in the area, because fish populations in the Powder Brook have died out in the past and the brook runs into a reservoir from which water is taken for drinking purposes.

The planner made an analysis of the water management problems in the area and then, along with the publication of the "Preliminary overview of major water management problems," it announced that sewage and wastewater treatment would be provided with respect to the facts identified in the Powder Brook basin.

\section{Data Collection}

As concerns cooperation of the municipalities, four individual and 11 coalition solutions can be theoretically assumed in this case The experts developing the analysis proposed a list of individual and coalition project designs for wastewater treatment that cannot be excluded beforehand for technical, economic, environmental, morphological, political, or other reasons (Table 1). To keep the case simple, only the most realistic location of the WWTP was considered for each project.

The analysis author collected data for each individual and coalition design pursuant to the list in Table 1 and entered them in the respective tables. The calculated wastewater production from the municipalities was entered in Table 2.

The collected data on the wastewater production in each locality (municipality) were used for calculating the data on pollution production monitored pursuant to Government Regulation No. 61/2003 Coll. [19], and ČSN 756401 [20], which specifies the daily production of $\mathrm{BOD}_{5}$ at $0.06 \mathrm{~kg} / \mathrm{EI}$, $\mathrm{P}_{\text {total }}$ at $0.0025 \mathrm{~kg} / \mathrm{EI}, \mathrm{N}_{\text {total }}$ at $0.015 \mathrm{~kg} / \mathrm{EI}$, and $\mathrm{N}_{-} \mathrm{NH}_{4}^{+}$at $0.011 \mathrm{~kg} / \mathrm{EI}$ (Table 3 ).

There is rich literature dealing with pollutants in rivers and lakes. The analyses of concrete situations at concrete sites always have to deal with the specific pollutants. While the basic indicators are usually the same or similar in different conditions, the experts deal with different pollutants. Every analysis should fit with the legislative requirements on the water quality, which is in new EU countries mostly harmonized with EU legislation. Readers of Polish Journal of Environmental Studies could meet several approaches of involving pollutants for analysis. For example, when determining the quality category of stream waters included in the small retention program in three areas of Malopolska in view of their use for public supplies of water intended for consumption, Kanownik et al. [21] investigated 20 physicochemical and two microbiological indicators. Indicators of $\mathrm{COD}_{\mathrm{Mn}}, \mathrm{BOD}_{5}, \mathrm{NH}_{3}-\mathrm{N}, \mathrm{TP}, \mathrm{TN}, \mathrm{F}$, surfactants (AS - alkylsulphate, $\mathrm{LAS}$ - linear alkylbenzene sulfonate), $\mathrm{SO}_{4}^{2-}$, and $\mathrm{Cl}$ were included in a study by Hezhong et al. [22]. Descriptive statistics of physico-chemical data of water temperature, dissolved oxygen, hardness, total nitrogen, total phosphorus, $\mathrm{N}: \mathrm{P}$, and chlorophyll- $a$ are provided for 13 Polish ponds in
Table 3. Data on proposed projects - calculated wastewater pollutant production.

\begin{tabular}{|c|c|c|c|c|c|}
\hline \multirow{6}{*}{$\begin{array}{c}\text { Project } \\
\text { No. }\end{array}$} & \multirow{6}{*}{$\begin{array}{c}\text { Project } \\
\text { title }\end{array}$} & $\mathrm{BOD}_{5}$ & $\mathrm{P}_{\text {total }}$ & $\mathrm{N}_{\text {total }}$ & $\begin{array}{c}\text { Suspended } \\
\text { solids }\end{array}$ \\
\cline { 3 - 7 } (kg/year) \\
\hline 1. & $\mathrm{~A}$ & 2,190 & 91.25 & 547.5 & 2007.5 \\
\hline 2. & $\mathrm{~B}$ & 5,475 & 228.125 & 1368.75 & 5018.75 \\
\hline 3. & $\mathrm{C}$ & 10,950 & 456.25 & 2737.5 & 10037.5 \\
\hline 4. & $\mathrm{D}$ & 16,425 & 684.375 & 4106.25 & $15,056.25$ \\
\hline & & Coalition projects \\
\hline 1. & $\mathrm{AB}$ & 7,665 & 319.375 & 1916.25 & 7026.25 \\
\hline 2. & $\mathrm{ABC}$ & 18,615 & 775.625 & 4653.75 & $17,063.75$ \\
\hline 3. & $\mathrm{BC}$ & 16,425 & 684.375 & 4106.25 & $15,056.25$ \\
\hline 4. & $\mathrm{CD}$ & 27,375 & $1,140.625$ & 6843.75 & $25,093.75$ \\
\hline 5. & $\mathrm{BD}$ & 21,900 & 912.5 & 5475.0 & $20,075.0$ \\
\hline 6. & $\mathrm{BCD}$ & 32,850 & $1,368.75$ & 8212.5 & $30,112.5$ \\
\hline 7. & $\mathrm{ABCD}$ & 35,040 & 1460 & 8760.0 & $32,120.0$ \\
\hline
\end{tabular}

[23]. A total of 25 VOCs (volatile organic compounds) and 38 SVOCs (semivolatile organic compounds) were selected from the "black list" of priority organic water pollutants jointly developed by China's Ministry of Environmental Protection in a study by Han et al. [24].

Table 4 shows the calculated pollution production after implementation of the individual (alternative) WWTP. The assumed treatment efficiency was set at $90 \%$ in all cases.

Table 4. Data on proposed projects - assumed wastewater pollutants production from WWTP after their implementation.

\begin{tabular}{|c|c|c|c|c|c|}
\hline \multirow{5}{*}{$\begin{array}{c}\text { Project } \\
\text { No. }\end{array}$} & \multirow{2}{*}{$\begin{array}{c}\text { Project } \\
\text { title }\end{array}$} & $\mathrm{BOD}_{5}$ & $\mathrm{P}_{\text {total }}$ & $\mathrm{N}_{\text {total }}$ & $\begin{array}{c}\text { Suspended } \\
\text { solids }\end{array}$ \\
\cline { 3 - 6 } & \multicolumn{5}{|c|}{ Individual projects } \\
\hline 1. & $\mathrm{~A}$ & 219 & 9.125 & 54.75 & 200.75 \\
\hline 2. & $\mathrm{~B}$ & 547.5 & 22.8125 & 136.875 & 501.875 \\
\hline 3. & $\mathrm{C}$ & 1,095 & 45.625 & 273.75 & $1,003.75$ \\
\hline 4. & $\mathrm{D}$ & $1,642.5$ & 68.4375 & 410.625 & $1,505.625$ \\
\hline & & Coalition projects \\
\hline 1. & $\mathrm{AB}$ & 766.5 & 31.9375 & 191.625 & 702.625 \\
\hline 2. & $\mathrm{ABC}$ & $1,861.5$ & 77.5625 & 465.375 & $1,706.375$ \\
\hline 3. & $\mathrm{BC}$ & $1,642.5$ & 68.4375 & 410.625 & $1,505.625$ \\
\hline 4. & $\mathrm{CD}$ & $2,737.5$ & 114.0625 & 684.375 & $2,509.375$ \\
\hline 5. & $\mathrm{BD}$ & 2,190 & 91.25 & 547.5 & $2,007.5$ \\
\hline 6. & $\mathrm{BCD}$ & 3,285 & 136.875 & 821.25 & $3,011.25$ \\
\hline 7. & $\mathrm{ABCD}$ & 3,504 & 146 & 876 & 3,212 \\
\hline
\end{tabular}


Table 5. Characteristics of watercourses to receive treated wastewater.

\begin{tabular}{|c|c|c|c|c|}
\hline $\begin{array}{c}\text { Assumed } \\
\text { WWTP location }\end{array}$ & $\begin{array}{l}\text { Receiving } \\
\text { watercourse }\end{array}$ & $\begin{array}{c}\text { Basic hydraulic characteris- } \\
\text { tics of watercourse }\end{array}$ & $\begin{array}{l}\text { Basic water quality } \\
\text { characteristics of watercourse }\end{array}$ & Remark \\
\hline A & Powder Brook & $\begin{array}{l}\text { Qmin } \\
\max . M, \ldots\end{array}$ & $\begin{array}{l}\mathrm{BOD}_{5}, \mathrm{COD}_{\mathrm{Cr}}, \text { Suspended solids, } \\
\mathrm{N}-\mathrm{NH}_{4}, \mathrm{P}_{\text {total }} \ldots\end{array}$ & \multirow{4}{*}{ salmon stream } \\
\hline B & Powder Brook & $\begin{array}{l}\text { Q } \\
\max . M, \ldots\end{array}$ & $\begin{array}{l}\mathrm{BOD}_{5}, \mathrm{COD}_{\mathrm{Cr}}, \text { Suspended solids, } \\
\mathrm{N}-\mathrm{NH}_{4}, \mathrm{P}_{\text {total }} \ldots\end{array}$ & \\
\hline $\mathrm{C}$ & Powder Brook & $\begin{array}{l}\mathrm{Q}_{\min }, \\
\max . \mathrm{M}, \ldots\end{array}$ & 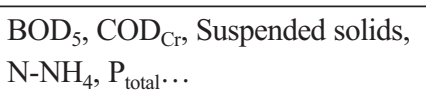 & \\
\hline $\mathrm{D}$ & Unnamed & $\begin{array}{l}\mathrm{Q}_{\min }, \\
\max . \mathrm{M}, \ldots\end{array}$ & $\begin{array}{l}\mathrm{BOD}_{5}, \mathrm{COD}_{\mathrm{Cr}}, \text { Suspended solids, } \\
\mathrm{N}^{-N_{4}}, \mathrm{P}_{\text {total }} \ldots\end{array}$ & \\
\hline $\begin{array}{l}\text { Outside } \\
\text { municipalities }\end{array}$ & $\begin{array}{l}\text { Confluence of Powder } \\
\text { Brook and Unnamed }\end{array}$ & $\begin{array}{l}\mathrm{Q}_{\min }, \\
\max . \mathrm{M}, \ldots\end{array}$ & $\begin{array}{l}\mathrm{BOD}_{5}, \mathrm{COD}_{\mathrm{Cr}}, \text { Suspended solids, } \\
\mathrm{N}^{-N_{4}}, \mathrm{P}_{\text {total }} \ldots\end{array}$ & $\begin{array}{l}\text { salmon stream, coalitions } \\
\text { BCD, and } \mathrm{ABCD}\end{array}$ \\
\hline
\end{tabular}

Table 6. Permissible minimum efficiency of treatment of wastewater discharged (minimum decrement percentage) in percentages, pursuant to Annex 1 to to Government Order No. 61/2003 Coll [19].

\begin{tabular}{|l|c|c|c|c|c|}
\hline $\begin{array}{c}\text { WWTP } \\
\text { category (EI) }\end{array}$ & $\mathrm{COD}_{\mathrm{Cr}}$ & $\mathrm{BOD}_{5}$ & ${\mathrm{~N}-\mathrm{NH}_{4}^{+}}^{+}$ & $\mathrm{N}_{\text {total }}$ & $\mathrm{P}_{\text {total }}$ \\
\hline$<500$ & 70 & 80 & - & - & - \\
\hline $500-2000$ & 70 & 80 & 50 & - & - \\
\hline $2001-10,000$ & 75 & 85 & 60 & - & 70 \\
\hline $10,001-100,000$ & 75 & 85 & - & 70 & 80 \\
\hline$>100,000$ & 75 & 85 & - & 70 & 80 \\
\hline
\end{tabular}

For discharges of treated wastewater into the receiving watercourse, the experts collected data on the watercourses into which the treated wastewater will be discharged in each location (Table 5).

The assessment of compliance with requirements for water discharge into surface waters again worked with requirements set by the Waters Act and its executive decrees (Tables 6 and 7).

Table 8 shows estimates of the respective one-off costs of the measurements included in analysis, with respect to specific conditions.
Direct investors' costs were introduced into the analysis. More social costs could be introduced in more detailed analyses.

\section{Computing Optimal Solution}

The mathematical model of the exercise for analysis is as follows:

$$
\begin{gathered}
N=6500 y_{\mathrm{A}}+16250 y_{\mathrm{B}}+29000 y_{\mathrm{C}}+32750 y_{\mathrm{D}}+ \\
27750 y_{\mathrm{AB}}+41750 y_{\mathrm{BC}}+59000 y_{\mathrm{BD}}+65000 y_{\mathrm{CD}}+50000 y_{\mathrm{ABC}}+ \\
69000 y_{\mathrm{BCD}}+73000 y_{\mathrm{ABCD}} \rightarrow \min \\
y_{\mathrm{A}}+y_{\mathrm{AB}}+y_{\mathrm{ABC}}+y_{\mathrm{ABCD}} \geq 1 \\
y_{\mathrm{B}}+y_{\mathrm{AB}}+y_{\mathrm{BC}}+y_{\mathrm{BD}}+y_{\mathrm{ABC}}+y_{\mathrm{BCD}}+y_{\mathrm{ABCD}} \geq 1 \\
y_{\mathrm{C}}+y_{\mathrm{BC}}+y_{\mathrm{CD}}+y_{\mathrm{ABC}}+y_{\mathrm{BCD}}+y_{\mathrm{ABCD}} \geq 1 \\
y_{\mathrm{D}}+y_{\mathrm{BD}}+y_{\mathrm{CD}}+y_{\mathrm{BCD}}+y_{\mathrm{ABCD}} \geq 1 \\
y_{h}(\mathrm{~S}) \in\{0,1\}, \forall \mathrm{S} \subseteq\{\mathrm{A}, \mathrm{B}, \mathrm{C}, \mathrm{D}\}, \forall \mathrm{h}, \mathrm{h}=1,2, \ldots, 11
\end{gathered}
$$

The optimum solution to this exercise is:

$$
\begin{gathered}
y_{\mathrm{A}}=0, y_{\mathrm{B}}=0, y_{\mathrm{C}}=0, y_{\mathrm{D}}=0, y_{\mathrm{AB}}=0, y_{\mathrm{BC}}=0, y_{\mathrm{BD}}=0, \\
y_{\mathrm{CD}}=0, y_{\mathrm{ABC}}=0, y_{\mathrm{BCD}}=0, y_{\mathrm{ABCD}}=1
\end{gathered}
$$

This means that one coalition project, $\mathrm{ABCD}$, should be proposed for implementation. The total costs are $\mathrm{N}=73,000$.

Table 7. Emission standards (mg/l) pursuant to Annex 1 to Government Order No. 61/2003 Coll [19].

\begin{tabular}{|l|c|c|c|c|c|c|c|c|c|c|}
\hline \multirow{2}{*}{$\begin{array}{c}\text { WWTP } \\
\text { category (EI) }\end{array}$} & \multicolumn{2}{|c|}{$\mathrm{COD}_{\mathrm{Cr}}$} & \multicolumn{2}{c|}{$\mathrm{BOD}_{5}$} & \multicolumn{2}{c|}{${\mathrm{N}-\mathrm{NH}_{4}^{+}}^{+}$} & \multicolumn{2}{c|}{$\mathrm{N}_{\text {total }}$} & \multicolumn{2}{c|}{$\mathrm{P}_{\text {total }}$} \\
\cline { 2 - 13 } & Average & Max. & Average & Max. & Average & Max. & Average & Max. & Average & Max. \\
\hline$<500$ & 150 & 220 & 40 & 80 & - & - & - & - & - & - \\
\hline $500-2000$ & 125 & 180 & 30 & 60 & 20 & 40 & - & - & - & - \\
\hline $2001-10,000$ & 120 & 170 & 25 & 50 & 15 & 30 & - & - & 3 & 8 \\
\hline $10,001-100,000$ & 90 & 130 & 20 & 40 & - & - & 15 & 30 & 2 & 6 \\
\hline$>100,000$ & 75 & 125 & 15 & 30 & - & - & 10 & 20 & 1 & 3 \\
\hline
\end{tabular}


Table 8. Estimated (one-off) cost of projects (in thousand of CZK).

\begin{tabular}{|c|c|c|c|c|c|c|}
\hline Project No. & Project title & WWTP & Sewage & Other facilities & Total costs & Remarks \\
\hline \multicolumn{7}{|c|}{ Individual projects } \\
\hline 1. & $\mathrm{~A}$ & 4,000 & 2,500 & None & 6,500 & \\
\hline 2. & $\mathrm{~B}$ & 10,000 & 6,250 & None & 16,250 & \\
\hline 3. & $\mathrm{C}$ & 14,000 & 12,500 & 2,500 & 29,000 & Pumping station for a hamlet \\
\hline 4. & $\mathrm{D}$ & 18,000 & 14,750 & None & 32,750 & \\
\hline \multicolumn{7}{|c|}{ Coalition projects } \\
\hline 1. & $\mathrm{AB}$ & 14,000 & 8,750 & 5,000 & 27,750 & Extra piping \\
\hline 2. & $\mathrm{BC}$ & 18,000 & 18,750 & 5,000 & 41,750 & Pumping station \\
\hline 3. & $\mathrm{CD}$ & 22,000 & 28,000 & 15,000 & 65,000 & Bridge over a brook, pumping station \\
\hline 4. & $\mathrm{ABC}$ & 23,000 & 23,000 & 4,000 & 50,000 & Pumping station \\
\hline 5. & $\mathrm{BD}$ & 20,000 & 39,000 & - & 59,000 & \\
\hline 6. & $\mathrm{BCD}$ & 26,000 & 28,000 & 15,000 & 69,000 & Bridge over a brook \\
\hline 7. & $\mathrm{ABCD}$ & 28,000 & 30,000 & 15,000 & 73,000 & \\
\hline
\end{tabular}

The costs of individual projects, which is a common practice, would be CZK 84.5 million. This solution therefore constitutes a savings of CZK 11.5 million compared to the implementation of individual projects only.

\section{Laboratory Pre-Tests of Subject Behavior}

A laboratory experiment was conducted in order to simulate the process of forming coalitions among municipalities when applying for subsidies for their pollution abatement projects. To approach reality as much as possible, real data were utilized in a process resembling an application for EU or Czech State Environmental Protection Fund subsidies. This is in line with the conclusions of Tisdell [25], who suggests that using real geophysical data can lead to different results than utilizing stylized ones. It is different from our first attempts to pretest similar hypotheses on subjects' behaviour, where ideal data were used [26].

The model presented in the previous section was used to calculate the optimal solution. Furthermore, rewards for the laboratory experiment participants (subjects) were designed in a way to copy the incentive structure faced by real representatives.

\section{Experimental Design}

Each subject represented one of four differently sized municipalities in the Powder Brook basin. This region was identical in all cases so the participants were divided into groups of four, and each foursome faced the same situation. The representatives were asked to address the pollution of the brook by constructing a WWTP. They could choose from individual or coalition projects, which could include two, three or four municipalities.
Each representative received only information about their own costs and funds and was not allowed to show it to others. It was thus concealed from participants which solution would be Pareto-optimal and motivated them to obtain information about the costs and funds of others through negotiations. At the same time, it was in their interest to pretend they had fewer funds at their disposal than was true because then they could free-ride in a coalition without others knowing.

The optimal solution was a coalition of all four parties, as shown in the previous section. The differences, however, were not so striking as to be noticed if players bid significantly less than they could (for information, the costs of the optimal solution $\mathrm{ABCD}$ were $86 \%$ of those of its opposite $\mathrm{A}+\mathrm{B}+\mathrm{C}+\mathrm{D})$.

Nevertheless, the players did not play only against the other three in their group. In order to be implemented, each project required a subsidy, as the maximum investment of each participant was set at $30 \%$ of their individual project costs, i.e. a willingness to contribute from their own municipality budget was introduced to the experiment. They were told that there were sufficient assets to subsidize only about $50 \%$ of the projects in the respective fund and that the ones requesting lowest subsidies relative to size would be selected.

The subjects were promised a basic show-up financial reward regardless of the result of their negotiation. They were, however, offered a bonus if their project obtained a subsidy (and could therefore be implemented) and a further bonus if they spent less than their maximum while still receiving the subsidy. This design was supposed to create a dilemma between deceiving project partners by bidding less and at the same time behaving responsibly not to jeopardize the success of the whole coalition.

The experiment was pilot tested on 3 groups of University of Economics, Prague master students of 
Table 9. Experiment results.

\begin{tabular}{|c|c|c|c|c|c|c|c|}
\hline \multirow{2}{*}{$\begin{array}{c}\text { Experiment } \\
\text { group No. }\end{array}$} & \multirow{2}{*}{$\begin{array}{c}\text { Coalition structure } \\
\text { (project group) }\end{array}$} & \multicolumn{2}{|c|}{ Total } & \multicolumn{4}{c|}{ Investment } \\
\cline { 3 - 8 } & & Costs & Subsidy & A & B & C & D \\
\hline 1 & $(\mathrm{AB}), \mathrm{C}, \mathrm{D}$ & 89,500 & 64,525 & 1,650 & 4,800 & 8,700 & 9,825 \\
\hline 2 & $(\mathrm{ABCD})$ & 73,000 & 49,560 & 1,900 & 4,140 & 7,800 & 9,600 \\
\hline 3 & $(\mathrm{ABCD})$ & 73,000 & 49,405 & 195 & 4,875 & 8,700 & 9,825 \\
\hline 4 & $(\mathrm{ABCD})$ & 73,000 & $49,726.5$ & $1,657.5$ & 4,831 & 6,960 & 9,825 \\
\hline 5 & $(\mathrm{ABCD})$ & 73,000 & 47,650 & 1,950 & 4,875 & 8,700 & 9,825 \\
\hline 6 & $(\mathrm{ABCD})$ & 73,000 & 53,650 & 1,850 & 2,000 & 5,700 & 9,800 \\
\hline 7 & $(\mathrm{ABC}), \mathrm{D}$ & 82,750 & 60,350 & 1,600 & 4,300 & 7,000 & 9,500 \\
\hline 8 & $(\mathrm{ABCD})$ & 73,000 & 48,000 & 1,700 & 4,800 & 8,700 & 9,800 \\
\hline
\end{tabular}

Environmental and Resource Economics and Policy courses. The feedback was incorporated into the final materials for the experiments.

\section{Experiment Results}

The experiments were conducted with eight student groups of four members each playing the roles of representatives of the municipalities located in the Powder Brook basin. The experiments took place in November 2013 with students of University of Economics Prague (16 students of the Decision Theory course, eight students of the Environmental Policy course and 8 students of the Public Administration of Environmental Protection course).

The optimal solution with respect to the total costs (coalition structure (ABCD), total costs 73,000 ) was compared with experimental results (Table 9).

Participants in the experiments created the optimal coalition structure $(\mathrm{ABCD})$ in six cases out of the eight groups. In one case (group 1 in Table 9), a two-member coalition (AB) plus two individual submissions were formed, and in one case (group 7), a three-member coalition $(\mathrm{ABC})$ plus one individual submission were formed. These coalitions, however, require higher costs than the optimal four-member coalition. Higher costs lead to higher subsidies required. Limited resources for provision of subsidies leads to a reduction in requirements for these subsidies. It is therefore interesting to analyze the results with respect to the magnitude of the subsidy required.

As mentioned in the experimental design, only $50 \%$ of the project groups (regions in reality) were supported as an expression of the scarcity of financial sources. So, participants in the individual groups competed among themselves and experimental groups competed with each other to obtain support and make it as high as possible. In our case, only 4 out of the 8 experimental groups (groups $2,3,5,8$ ) received subsidies. All these groups concluded their negotiations with the optimal coalition structure. The highest support received was 49,560 for group 2 .
Negotiations among the group members regarding the value of their investments, which would complement support to total costs, were also important. The investment structures for groups 2,5 , and 8 were substantially similar. The investment by member A was very low in group 3 in comparison with the other groups. This raises a presumption that the participants agreed in favour of A, to maximize the benefit of the remuneration policy and subsequently split the win.

\section{Conclusions}

While tackling problems connected to environmental protection where for minimizing the social costs it is efficient to create coalitions and apply for subsidies for joint projects, the theory of combinatorial auctions can provide a good theoretical background. At the same time, the theory itself can be enriched through examining such cases.

In the paper one can find the case of the high-priority basin of the Powder Brook, where the priority is to improve water quality for drinking purposes and for biodiversity protection. There are several polluters in the basin, who in the case they cooperate, i.e., realize common projects on cleaning the water, can save social costs, and share the extra cake created.

The presented model can serve for computing optimal solutions in situations where we trust expert estimates of abatement costs. It could be a situation of the costs of municipal WWTPs. In the case of asymmetric information, i.e., where subjects do not share information on their costs with other polluters and/or the authority, the model can still be useful:

(i) For computing the structure of the coalition projects submitted to minimize spending from the fund

(ii) For computing the theoretically optimal solution for testing various hypotheses on subjects' behaviour under various institutional settings and behavioural rules in laboratory experiments

This study takes advantage of the latter option and designs an experiment that copies the incentive structure of 
the actual municipalities. Such a setting should be able to indicate whether it is possible to achieve an optimal solution in the real world. The results seem to be very optimistic in this respect. Participants tended to realize the savings offered by coalition projects; out of the eight groups, there were six coalitions of four (which was the optimal solution), one coalition of three, one coalition of two, and only three individual projects. Furthermore, the subsidies required tended to be relatively low, making the competition for subsidies very stiff; the fourth-best offer (the last one to obtain the subsidy) requested $104 \%$ of the minimum subsidy (i.e., a case where every representative bids their entire funds).

The experiment was proposed to match the situation of real municipality representatives as closely as possible. However, this means that it cannot be easily described using game theory terminology. For a more game theoryfocused approach, see [27]. It may be an interesting challenge for future research to replicate the experiment with slightly alternated parameters or stricter limitations on the means of negotiations.

\section{Acknowledgements}

This paper was supported with a grant from the Czech Science Foundation, GACR No. 13-07036S: "Modelling of Negotiations in Environmental Policy under Information Asymmetry."

Experiment instructions distributed to subjects are available from Petr Šauer.

\section{References}

1. Council Directive 91/271/EEC of 21 May 1991 concerning urban waste-water treatment, 1991.

2. PEREZ M. A New Strategy to Improve Water Quality - One Targeted Watershed at a Time, World Resource Institute, 2014,

http://www.wri.org/blog/new-strategy-improve-water-quality $\%$ E2\%80\%94one-targeted-watershed-time?utm_campaign $=$ socialmedia\&utm_source=facebook.com\&utm_med ium=wri-page, approached January 8, 2014.

3. KEMPER K.E., BLOMQUIST W., DINAR A. (Ed.). Integrated river basin management through decentralization. Springer, 2007.

4. FRIESEN L., GANGADHARAN L. Environmental markets: What do we learn from the lab? Journal of Economic Surveys, Special Issue: A Collection of Surveys on Market Experiments 27, (3), 515, 2013.

5. CRAMTON P., SHOHAM Y., STEINBERG R (Eds.). Combinatorial Auctions, MIT Press, Cambridge, 2006.

6. PEKEČ A., ROTHKOPF M. H. Combinatorial auction design. Manage. Sci. 49, (11), 1485, 2003.

7. SCHEFFEL T., ZIEGLER G., BICHLER M. On the impact of package selection in combinatorial auctions: an experimental study in the context of spectrum auction design. Experimental Economics 15, (4), 667, 2012.

8. ŠSAUER P., DVOŘÁK A., LISA A., FIALA P. A procedure for negotiating pollution reduction under information asym- metry. Surface water quality case. Environ. Resour. Econ. 24, (2), 103, 2003.

9. ŠSAUER P., FIALA P., DVOŘÁK A. Modelling of environmental risk management under information asymmetry. In: Environmental Software Systems. Fostering Information Sharing. Springer Berlin Heidelberg, pp. 391, 2013.

10. MURPHY J.J. DINAR A., HOWITT R., RASSENTI S., SMITH V. The Design of "Smart" Water Market Institutions Using Laboratory Experiments. Environ. Resour. Econ. 17, (4), 375, 2000.

11. Directive 2000/60/EC of the European Parliament and of the Council of 23 October 2000 establishing a framework for Community action in the field of water policy, 2000.

12. Act No. 254/2004 Coll. on Waters and amendment to certain acts of law (the Water Act), 2004.

13. Act No. 274/2001 Coll. on Water Mains and Sewerage Systems, 2001.

14. Decree No. 24/2011 Coll. on Catchment Plans and Flood Risk Management Plans, 2011.

15. Decree No. 393/2010 Coll. on Catchment Areas, as amended by Decree No. 390/2004 Coll., 2010.

16. ŠAUER P., DVOŘÁK A., FIALA P., PRÁS̆EK J. Methodology for economic and environmental optimisation of reducing pollution in watercourses, University of Economics \& Ministry of Agriculture, certificate No. 79469/2013-MZe, Prague, 2013.

17. Act No. $100 / 2001$ Coll. on Environmental Impact Assessment and Amending Some Related Acts. 2001.

18. FIALA P. KALČEVOVÁ J., VRANÝ J. CRAB CombinatoRial Auction Body Software System. Journal of Software Engineering and Applications 3, (7), 718, 2010.

19. Government Order of 29 January 2003 No. 61/2003 Coll., on the indicators and values of permissible pollution of surface water and wastewater, mandatory elements of the permits for discharge of wastewater into surface water and into sewerage systems, and on sensitive areas (Czech Technological Norm; 2003 [In Czech].

20. ČSN 756401 Sewage treatment plants for more than 500 of population equivalents.

21. KANOWNIK W., KOWALIK T., BOGDAŁ A., OSTROWSKI K. Quality Categories of Stream Waters Included in a Small Retention Program. Pol. J. Environ. Stud. 22, (1), 159, 2013.

22. YUAN H., LIU E., PAN W., AN S. Water Pollution Characteristics and Assessment in Different Functional Zones. Pol. J. Environ. Stud. 23, (2), 541, 2014.

23. JAROSIEWICZ A., RADAWIEC B., HETMAŃSKI T. Influence of Water Chemistry and Habitat Parameters on the Abundance of Pond-Breeding Amphibians. Pol. J. Environ. Stud. 23, (2), 349, 2014.

24. HAN F., CHEN J., JIANG Z., CHEN L., JI W. Volatile and Semi-Volatile Organic Compounds in the Lower Yangtze River and Surface Waters of Three Chinese Provinces. Pol. J. Environ. Stud. 22, (3), 683, 2013.

25. TISDELL J. Bringing biophysical models into the economic laboratory: An experimental analysis of sediment trading in Australia. Ecol. Econ., 60, (3), 584, 2007.

26. FIALA P., ŠAUER P. Application of Combinatorial Auctions on Allocation of Public Financial Support in the Area of Environmental Protection: Economic Laboratory Experiment. Politická Ekonomie, 59, (3), 379, 2011.

27. MADANI K. Game theory and water resources. J. Hydrol., 381, (3), 225, 2010. 
